\title{
Yield Stability of Contrasting Orchardgrass (Dactylis Glomerata L.) Genotypes Over the Years and Water Regimes
}

Fatemeh Saeidnia ( $\square$ f.saeednia@alumni.iut.ac.ir)

Isfahan University of Technology https://orcid.org/0000-0001-7206-8651

Mohammad Mahdi Majidi

Isfahan University of Technology

Aghafakhr Mirlohi

Isfahan University of Technology

Mohammad Reza Dehghani

Isfahan University of Technology

Behnam Hosseini

Isfahan University of Technology

\section{Research Article}

Keywords: Combining ability, GGE biplot, orchardgrass, polycross mating, synthetic variety

Posted Date: March 1st, 2021

DOl: https://doi.org/10.21203/rs.3.rs-264586/v1

License: (9) This work is licensed under a Creative Commons Attribution 4.0 International License.

Read Full License 
3

Yield stability of contrasting orchardgrass (Dactylis glomerata L.) genotypes over the years and water regimes

\section{F. Saeidnia, M. M. Majidi, A. Mirlohi, M. R. Dehghani, and B. Hosseini}

\section{Fatemeh Saeidnia}

Postdoctoral Researcher of Plant Breeding, Department of Agronomy and Plant Breeding, College of Agriculture, Isfahan University of Technology, Isfahan, 84156-83111, Iran

Email: f.saeednia@ alumni.iut.ac.ir

ORCID Identifier: 0000-0001-7206-8651

\section{Mohammad Mahdi Majidi}

Professor of Genetics and Plant Breeding, Department of Agronomy and Plant Breeding, College of Agriculture, Isfahan University of Technology, Isfahan, 84156-83111, Iran

Email: majidi@iut.ac.ir

ORCID Identifier: 0000-0003-4746-9036

\section{Aghafakhr Mirlohi}

Professor of Genetics and Plant Breeding, Department of Agronomy and Plant Breeding, College of Agriculture, Isfahan University of Technology, Isfahan, 84156-83111, Iran

Email: $\underline{\text { mirlohi@iut.ac.ir }}$

ORCID Identifier: 0000-0002-3445-5770

\section{Mohammad Reza Dehghani}

Former PhD student of Plant Breeding, Department of Agronomy and Plant Breeding, College of Agriculture, Isfahan University of Technology, Isfahan, 84156-83111, Iran

E-mail: m.r.dehghani@vru.ac.ir

\section{Behnam Hosseini}

Former MSc student of Plant Breeding, Department of Agronomy and Plant Breeding, College of Agriculture, Isfahan University of Technology, Isfahan, 84156-83111, Iran

Email: behnamhosseini2000@yahoo.com

\section{Acknowledgments}

The authors would like to thank the Iran National Science Foundation (INSF) [grant number 98025737] and Isfahan University of Technology (IUT) for supporting this work. 
1 Abstract

2 Stability of combining ability and the nature and extent of genetic and genotypexenvironment 3 interaction is poorly understood in orchardgrass especially under climate change conditions. In the 4 present study, first-generation half-sib families of orchardgrass derived from the polycross of 25 5 parental genotypes were evaluated in the field during five years under two irrigation regimes of 6 normal and water deficit. Considerable genotypic variation was observed among half-sib families for

7 all of the evaluated traits, demonstrating high potential for improving these traits through half-sib 8 mating. The effects of water deficit on dry forage yield increased from the first to fifth year and 9 consequently declined the persistence of half-sib families. Results showed that both genetic and nongenetic gene actions played a role in the control of dry forage yield; indicating that selection based on an index would be more useful to attain genetic progress. Moreover, the estimates of narrow-sense heritability for most of the traits were higher under deficit irrigation, which is advantageous for successful selection. The stability of general combining ability, plant productivity, and drought tolerance clearly identified G4, G5, G6, and G14 as the superior and stable parental genotypes able to transmit both stability and forage productivity to their progenies.

Keywords: Combining ability- GGE biplot- orchardgrass- polycross mating- synthetic variety.

\section{Introduction}

Growth and productivity of plants are affected by a wide range of biotic and abiotic stresses such as severe temperatures, excessive light, nutrient deficiencies, salinity, drought, and cold (Chaves et al. 2009; Crisp et al. 2016). Among them, drought is the most significant and acute problem which adversely affects growth, survival, persistence, and productivity of plants in arid and semi-arid 
1 regions of the world (Cai et al. 2011; Ciais et al. 2005) and is expected to become increasingly

2 important due to desertification and climate change (Cullen et al. 2009; IPCC 2014).

3 Effective adoption of perennial forage grasses as an alternative to annuals depends on their ability to

4 survive successive summer droughts and retain forage productivity, which is defined as persistence

5 (Annicchiarico et al. 2011). Under drought stress conditions, perennial forage grasses such as

6 orchardgrass can be valuable alternative to annuals because they offer higher optimization of

7 available water due to higher and faster growth at the beginning of autumn rains and more efficient

8 exploitation of residual soil water in late spring. The ecophysiological bases of persistence in

9 orchardgrass are relatively well known; but the genetic determinism of this persistence is not so well known.

In most forage species, half-sib (HS) matings, including polycross and open-pollination are widely used for estimation of general combining ability of parental clones for the development of synthetic cultivars, the nature and relative extent of genetic variability and heritability in quantitative genetic studies (Araujo et al. 2002; Aastiveit and Aastiveit 1990). Estimates of variance components are used to determine the proportion of total genetic variance due to additive genetic effects (heritability) and predict genetic gain from selection. Since the genetic variance among HS families is equal to the covariance between HS individuals and to one-fourth of the additive genetic variance (assuming there is no additive $\mathrm{x}$ additive types of epistatic variance), estimation of heritability based on analysis of HS family gives a good prediction of narrow-sense heritability $\left(\mathrm{h}^{2}{ }_{\mathrm{n}}\right)$ (Nguyen and Sleper 1983; Amini et al. 2013).

As a multi-layered factor, drought stress causes genotype by environment (GE) interactions. Therefore, understanding genotype $\times$ environment interaction (GEI) is an essential and challenging issue among plant breeders and agronomists. GEI usually hinders the accuracy of yield estimation, 
1 reduces the association between genotypic and phenotypic values, leads to bias in the estimation of

2 heritability and in the prediction of genetic advance, and complicates the process of selecting 3 genotypes with superior performance (Gauch 2006; Oral et al. 2018). Different methods have been 4 used to study and interpret $\mathrm{G} \times \mathrm{E}$ interaction. These methods include univariate linear regression 5 models (Finlay and Wilkinson 1963; Eberhart and Russell 1966) and multivariate models such as 6 Additive Main effects and Multiplicative Interactions (AMMI) (Zobel et al. 1988) and 7 GenotypexGenotype-Environment interaction (GGE) biplot (Yan 2001). Among these, GGE biplot is 8 more interpretative and has been recognized as preferred tool to analyze and visualize the pattern of 9 GEI in multi environment studies (Brar et al. 2010; Jandong et al. 2011). GGE biplots have been 10 identified as an effective tool in mega-environment analysis, genotype and environment evaluation, trait-association and trait-profile analyses, and heterotic pattern analysis (Amira et al. 2013; Zhang et al. 2016; Teodoro et al. 2015). They have thus been increasingly used in GE interaction studies in plant breeding (Samonte et al. 2005; Dehghani et al. 2006; Kaya et al. 2006; Blanche et al. 2007).

However, there has been no report of its application to orchardgrass so far.

Little information is available about the nature and extent of GE interactions effects using HS families in cool season grasses. Such information could simplify selection of parents able to transmit high persistence, forage yield, and stability under drought to develop new synthetic cultivars. Accordingly, this study attempted to i) assess the genetic basis of agro-morphological traits, persistence, and drought tolerance of Iranian and foreign HS families of orchardgrass derived from polycross, ii) estimate general combining ability for dry forage yield of parental genotypes of preceding HS families and evaluate its stability in order to select superior genotypes, iii) visually assess the adaptability and forage yield stability of orchardgrass families across 10 environments based on the GGE biplot in order to facilitate comparison among HS families and environments and 
1 iv) identify suitable families in terms of drought tolerance, persistence, and stability for future

2 breeding studies.

$4 \quad$ Materials and Methods

\section{Experimental site}

6 This research was conducted during five years (2010-2014) on a Typic Haplargid, silty clay loam soil

7 at the research farm of the Isfahan University of Technology, located in Lavark, Najaf-Abad, Isfahan, 8 Iran $\left(32^{\circ} 30^{\prime} \mathrm{N}, 51^{\circ} 20^{\prime} \mathrm{E} ; 1630 \mathrm{~m}\right.$ amsl). According to the classification of Koppen, this region had 9 a semi-arid and cold climate with dry summers and had a mean annual rainfall and temperature of 10 $140 \mathrm{~mm}$ and $14.5^{\circ} \mathrm{C}$, respectively. In this region, there is no rain during the summer (from late May to mid-October) and supplemental irrigation is needed for growing crops during this period.

\section{Plant materials}

In this study $25 \mathrm{HS}$ families derived from the polycross of 25 parental genotypes of orchardgrass were used as genetic material (Table 1). The parental genotypes of the polycross were selected based on agronomical and morphological data from previous studies. To produce half-sib (HS) progeny families of these parental plants, they were polycrossed in an isolated nursery with eight replications.

In June 2009, seeds from each genotype were harvested per replication and mixed together in equal proportions. A random sample was taken out in the bulked seed lot of each parental genotype to grow

25 HS families. Polycross seeds were grown in plastic boxes in a greenhouse during the winter of

2010. In March of 2010, the established and uniform seedlings were space planted in the field according to a randomized complete block design with four replications. In each plot, 20 seedlings of 
1 a given family were planted in two rows with $40 \mathrm{~cm}$ apart and $40 \mathrm{~cm}$ between plants within row. The

2 distance between neighboring plots was $60 \mathrm{~cm}$.

\section{$4 \quad$ Evaluation of HS families}

5 After establishment of HS families, one half of the replications were assigned to the normal irrigation and the other half were allocated to deficit irrigation for five years (during the 2010-2014 growing seasons). Under the normal and deficit irrigations, water was supplied when $50 \%$ and $85 \%$ of the total available soil moisture (field capacity) was depleted from the root zone respectively, according to the methods of determination of evapotranspiration proposed by Allen et al. (1998). Water deficit treatment was continuously applied during the growing season (from the first of May to the first of October) of each year. To determine the amount of irrigation water needed to restore the soil moisture to the field capacity and determine the irrigation times, soil samples were taken from different sites of each irrigation regime before irrigation at depths of 0-20, 20-40, and 40-60 cm, using a hand auger and the gravimetric soil-water content was measured (Clarke Topp et al. 2008). A volumetric counter was used for measurement of the supplied water for each irrigation regime.

The following plant measurements were undertaken during five years. Days to panicle emergence (DPE) and days to anthesis (DA) were recorded as the time from March 1st until appearance of three panicles in each plant and onset of pollen shedding, respectively. At full anthesis, the distance from the plant base to the top of the three tallest panicles was measured and considered as plant height (PHT). Number of fertile stems per plant (NS) was recorded the pollination stage. Crown diameter (CD) was measured as the width of plant basal cover remaining after the first cut. After the complete flowering (about early summer), the produced forage of each HS family was harvested by cutting the grass from $5 \mathrm{~cm}$ above the ground and the harvested materials were then 
1 dried at $75^{\circ} \mathrm{C}$ for $48 \mathrm{~h}$. The dry forage yield per family (DFY1) was then computed. To assess

2 complete growth, a second cut was undertaken in late summer and the dry forage yield was recorded

3 (DFY2) following the same protocol as for the first cut. Percentage of dry matter in forage yield was

4 calculated at each cut (PDFY1 and PDFY2). The drought tolerance index (STI) (Fernandez 1992)

5 was calculated based on the DFY $\left(\mathrm{g} \mathrm{plot}^{-1}\right)$ under normal and deficit irrigation regimes using the

6 following formulae:

$7 \quad \mathrm{STI}=(Y \mathrm{~s} i \times Y \mathrm{p} i) /(Y \mathrm{mp})^{2}$

$8 \quad$ where $Y \mathrm{~s} i$ is the yield of the $i$ th family in the deficit irrigation, $Y \mathrm{p} i$ is the yield of the $i$ th family in the

9 normal irrigation, and $Y \mathrm{mp}$ is the yield mean over all families in the normal irrigation. The

persistence (PER) of HS families was calculated on the combined data of two irrigation regimes by

subtracting the DFY of first cut in the second year (2014) from the DFY of first cut in the fifth year (2011).

\section{Statistical analyses}

In the stability analysis, a combination of a single year and irrigation regime was considered as the test environment; thus, 10 test environments were created (Online Resource 1). The Bartlett's test and Kolmogorov-Smirnov method were used to examine the homogeneity of residual variance and normality distribution of data, respectively. Combined analysis of variance was performed to examine the effect of the irrigation regimes, years, families, and their interactions, using Proc GLM of SAS release 9.4 (SAS Institute, Cary, NC, USA). As the experiment was conducted for 5 years in two irrigation regimes, a split-plot in time (year) model was used for this analysis as proposed by Steel and Torrie (1980) and Nguyen and Sleper (1983). The effects of irrigation regime were considered as 
1 fixed, and year was considered as random effect. Mean comparison was conducted using the LSD test

2 at $P<0.05$ (Steel and Torrie 1980).

Data were also subjected to ANOVA separately for normal and deficit irrigation across five years

4 using a split-plot in time model with HS families as the main plots and years as subplots. Variance

5 components were estimated for individual irrigation regime (normal and water deficit conditions)

6 from mean squares of the ANOVA after being equated to their expected variance components

7 (Nguyen and Sleper 1983). The estimation of narrow-sense heritability was calculated on the basis of

8 family means for normal and deficit irrigation regimes, using the following equation (Nguyen and

$9 \quad$ Sleper 1983):

$10 \quad h_{n H S}^{2}=\frac{\sigma_{f}^{2}}{\sigma_{f}^{2}+\frac{\sigma_{f y}^{2}}{y}+\frac{\sigma_{f r}^{2}}{r}+\frac{\sigma_{e}^{2}}{y r}}$

11 where $h_{n}^{2}$ is the narrow-sense heritability, $\sigma_{f}^{2}$ is the family variance, $\sigma_{f y}^{2}$ is the family $\times$ year variance, and $\sigma_{e}^{2}$ is the residual variance, while $\mathrm{y}$ and $\mathrm{r}$ represent the number of years and replications, 13 respectively. The level of genetic variation was estimated with the calculation of genotypic 14 coefficient of variation (GCV) as follow:

$15 \mathrm{GCV}=\left(\sigma_{\mathrm{g}} / \mu\right) 100$

where $\sigma_{\mathrm{g}}$ is the square root of the genotypic variance and $\mu$ is the phenotypic mean. General combining ability (GCA) was calculated on the combined data of two irrigation regimes as the deviation of each HS family from the population mean as defined by Wricke and Weber (1986).

\section{Stability analysis}


1 In the present study, analysis of adaptability and phenotypic stability was conducted by the GGE

2 biplot, using the model outlined by Yan (2002). The data were graphically analyzed for interpreting

3 the GE interaction to identify stable and adaptive HS families by the GGE biplot, as described by Yan

4 and Tinker (2006). This methodology uses a biplot to show the factors (G and GE) that are important

5 in genotype evaluation and that are also the sources of variation in GE interaction analysis of MET

6 (multi-environmental trial) data (Yan et al. 2000, 2001). For this purpose, the first two components

7 that resulted from singular value decomposition (SVD) using MATLAB programming language were

8 used to draw the desired biplots with Microsoft Office Excel 2016. The remaining PCs were regarded

9 as residuals (Yan and Tinker 2006).

\section{Results}

\section{Analysis of variance and genetic analysis}

Results from the ANOVA showed that there were significant differences between the normal and deficit irrigation regimes for all of the measured traits except for DPE and DA. The effect of family was significant for all traits, indicating significant variation among the selected families. Family $\times$ irrigation regime effects were also significant for most of the traits (Tables 2 and Online Resource 2).

Moreover, significant differences were observed among HS families from Iranian parental genotypes on one hand and from foreign parental genotypes on the other hand for most of the studied traits. Meanwhile, the Iranian vs. foreign effect was only significant for PDMY1 and DFY (Tables 2 and

Online Resource 2). The environment effect was a predominant source of variation which explained $58.6 \%$ of total variation, whereas G and GE captured $4.2 \%$ and $21.5 \%$, respectively (Table 2). The 
1 value decomposition, accounted for $65 \%$ and $11 \%$ of the GGE sum of squares respectively, 2 explaining a total of $76 \%$ variation (Figs. 2-6).

Mean comparisons showed that under the drought stress condition, the mean performance was

4 decreased for some of the evaluated traits (PH, NS, CD, DFY1, and DFY2), while it was significantly

5 increased for the remaining traits (DPE, DA, PDFY1, and PDFY2) during 2010-2014 (Table 3). As

6 expected, drought stress strongly reduced dry forage yield of cut 1 (DFY1), dry forage yield of cut 2

7 (DFY2), and mean dry forage yield (MDFY) during five consecutive years of experiment. Compared

8 with normal condition, drought stress approximately reduced DFY1 by 22, 30, 65, 69, and 30\%

9 during 2010-2014. For DFY2, these reductions were approximately 17, 45, 62, 65, and 42\%, in the

same five years relative to normal condition (Table 3). To assess drought tolerance of the orchardgrass families, the STI index was calculated. The highest values of STI were obtained for F4 (from Hungary), F18 (from Hungary), and F7 (from Isfahan, Iran), and the lowest values were detected for F3 (from Najafabad, Iran), F12, and F16 (both from Isfahan, Iran) (Table 1; Fig. 1a). Moreover, prolonged water deficit was applied in five consecutive years and reduced the persistence of HS families (data not shown). Based on the biplot depicted in Figure 1a, the higher values of persistence were observed for HS families F23 (from Isfahan, Iran), F11 (from Hungary), F12 (from Isfahan, Iran), F21, and F22 (both from Hungary), respectively. The families of F6, F18 (both from Hungary), F7 (from Isfahan, Iran), and F15 (from Semnan, Iran) had the lower persistence, respectively (Fig. 1a).

For most of the evaluated traits, the genetic variation was higher under deficit irrigation than under normal irrigation. Based on GCV, highest range of genetic variation was observed for NS and relatively lower one was detected for PDFY2 and DA (Table 4). The estimates of narrow-sense heritability and variance components for each irrigation regime are displayed in Table 3. According 
1 to the results, heritability estimates ranged from $14.33 \%$ for DFY2 to $57.36 \%$ for DA in normal

2 irrigation and from $25.66 \%$ for DFY2 to $75.35 \%$ for DPE in deficit irrigation. Higher heritability

3 estimates were obtained under deficit irrigation for most of the studied traits. Moreover, in both the

4 normal and deficit irrigation regimes, the heritability of yield components (such as PH, NS, and CD)

5 was higher than that of forage yield (Table 4).

In the present study, HS families showed a wide range of general combining ability (GCA) for and F7 (from Isfahan, Iran) (Table 1). Therefore, these genotypes are good combiners for forage yield and may be suggested for developing synthetic varieties. Parental genotypes F18 (from Hungary), F16 (from Isfahan, Iran) and F15 (from Semnan, Iran) had relatively low GCA for DFY and, hence, are not good combiners. GCA had a significant and positive correlation with STI (Fig. 1a); therefore it is possible to identify genotypes having high values of combining ability and drought tolerance at the same time. In this respect, some families including F4 (from Hungary) and F7 (from Isfahan, Iran), were identified as superior (Fig. 1b).

\section{Stability analysis based on GGE biplot}

In this study, GE interaction effect was highly significant and explained $21.55 \%$ of total variation of

DFY (Table 2). As significant GEI complicates the selection process through minimizing the association between genotypic and phenotypic values; therefore, there is a need for the stability analysis. The GGE biplot analysis showed that the first two PC accounted for $65 \%$ and $11 \%$ of the G+GE sum of squares respectively, explaining a total of $76 \%$ variation (Figs. 2-6).

To effectively visualize the "which-won-where" pattern of the interaction between HS families and environments and also to interpret their biplot for DFY, the polygon view of the GGE biplot is 
1 shown in Figure 2. In the polygon biplot analysis, the families located on the vertices of the polygon,

2 i.e. F3, F5, F11, F13, and F18, are the best or worst ones in one or more environments, because they

3 have the largest distances from the biplot origin in their direction and therefore, are considered

4 specifically adapted (Yan et al. 2007). Moreover, the family F3 was the highest yielding family at the

5 environments E4 and E10; family F5 produced the highest yield at environments E6 and E8; F11

6 showed high yield at E5 and E7; and family F18 was identified as the winner family at E1, E2, E3,

7 and E9, because these environments were located in their related sections, respectively. The vertex

8 family F13 was not the highest yielding family at any environment, because it felled in the section

9 where there was not any environment at all (Fig. 2).

The mean forage yield and stability performance of HS families are graphically visualized through the average environment coordination (AEC) method (Fig. 3). In this method, the abscissa and the ordinate axes of the AEC are defined by the average PC1 and PC2 of all environments to approximate the mean forage yield and stability performance of HS families. Projections of HS families onto the AEC abscissa approximate the mean forage yield of the families. The families farthest from the origin would have higher (on the positive side of the AEC abscissa) or lower (on the negative side of the AEC abscissa) mean forage yield. According to Fig. 3, the families were divided into two groups. The first group, with above-average performance, included F15, F10, F1, F9, F13, F2, F4, F6, F7, F18, F8, F11, F14, and F5, respectively. The second group that included the remaining families had below average performance. An ideal genotype should have the highest mean performance of all genotypes and be absolutely stable to show wide adaptability in the wide range of environments (Sharma et al. 2010; Akcura et al. 2011). Therefore, considering both forage yield and stability performance, F6 and F14 were more stable as well as relatively high yielding in terms of forage and could be regarded as the most favorable HS families. 
The performance of the family in the respective environment can be determined based on the angle between the vector of each HS family and the vector of each environment (Yan and Tinker 2006). The angle of less than $90^{\circ}$ shows the better performance than the average; the angle of more than $90^{\circ}$ indicates poorer performance than the average; and the angle of about $90^{\circ}$ demonstrates that the family performs near the average. For example, in E3, E6, E8, and E9 the families F2, F4, F5, F6, F7, F8, and F14 showed performance better than the average, the families F1, F9, F10, F11, F13, F22, and F25 performed near the average, and the families F3, F12, F15, F19, F20, F21, and F24 had poorer performance (Fig. 4).

The GGE biplot analysis allows comparison among genotypes in respect to a reference genotype named "ideal genotype". An ideal genotype is defined as one that is the highest yielding across all environments and is absolutely stable in performance (Yan and Tinker 2006). In this context, the desirable genotypes are those located close to the ideal genotype on the biplot. According to the idealgenotype view (Fig. 5), families F14, F5, F6, and F4 are positioned closest to the ideal genotype on the biplot and could be considered as desirable HS families. These families seem to be widely adapted across environments. On the other hand, the lower yielding families i.e. F3, F21, F12, F24, and F19, are unfavorable ones; because they are located far away from the ideal genotype, respectively (Fig. 5).

The discriminating power and representativeness view of the GGE biplot is indicated in Figure 6. In the biplot, the environments having longer vectors have more discriminating power of the genotypes and vice versa (Yan et al. 2007). Another important feature of an environment is its representativeness of the other environments, which is measured based on the angle between the environment vector and the "average environment coordinate" (AEC) axis. The environments which have small angle with the AEC are more representative of other environments. In this study, E3, E7, 
1 and E5 had the long vectors and therefore were the most discriminating environments (Fig. 6).

2 Among them, two environments of E5 and E7, which had wide angles with the AEC, were not

3 representative of the other environments and therefore, not useful for selecting the superior HS

4 families. On the other hand, E10 with the shortest vector length was the least discriminating

5 environment; and the environments E9, E6, and E8 were in the next ranks, respectively; and therefore

6 provide little or no information about the families' variability (Jalata 2011; Yan and Tinker 2006).

7 Environments E8, E6, E9, and E3 with the lower angles from the AEC axis were the most

8 representative environments, respectively. Among these environments E6, E8, and E9 were low

9 discriminative environments, due to the short vector length. However, the E4 environment was the

least representative environment due to the wider angle with AEC axis, followed by E10 and E1. Environment E8 had relatively high discriminating power and representativeness. Therefore, this environment can be used to effectively select superior HS families which can perform consistently best across all of the environments.

\section{Discussion}

Combined analysis of variance indicated that all the main effects (families, irrigation regimes, and years) and all of the interactions significantly influenced DFY and all of the other traits evaluated in the present study. Significant variation among HS families revealed that there is considerable genotypic variation for forage yield and its components. The significant GE interaction demonstrated the different response of genotypes to environmental variations. Therefore, it was possible to proceed and calculate phenotypic stability. The GE effect was about five times greater than the $\mathrm{G}$ effect of the total variation, suggesting the possible existence of different mega environments with different topyielding genotypes (Yan and Kang 2003). This along with a highly significant GEI indicated the need 
1 for the stability analysis. Moreover, the large yield variation due to environment, which is irrelevant

2 to cultivar evaluation and mega environmental investigation, justifies selection of SREG procedures

3 for analyzing the MET data (Segherloo et al. 2010). This is the reason that E is removed from the

4 observed phenotypic data, which helps to concentrate on genotype and GE, which are relevant for 5 genotype evaluation (Yan and Kang 2003; Fan et al. 2007).

Water deficit caused a significant reduction in all of the measured traits except for DPE and DA in five years of study. As water deficit was applied each year from 1 May onwards, which coincided exactly with the start of flowering and just before pollination, these results were expected and are consistent with the findings of previous studies in orchardgrass (Saeidnia et al. 2017; Majidi et al. 2016) and smooth bromegrass (Abtahi et al. 2019; Saeidnia et al. 2020). The region in which the study was conducted (Najafabad, Isfahan, Iran) is a warm and dry area where the summer temperature reaches as high as $45^{\circ} \mathrm{C}$ and precipitation is null. Therefore, reductions are expected in most of the evaluated traits.

Genotypic coefficients of variation $(\mathrm{GCV})$ for most of the measured traits under the deficit irrigation regime were higher than their estimates under the normal one, which suggests that selection under deficit irrigation may be more effective. The findings in this context are contradictory. For example, some researchers stated that GCV and genetic gain through selection is higher under normal irrigation than deficit irrigation (Blum 2011; Majidi et al. 2016). While others reported higher GCV and genetic advance through selection under deficit irrigation (Abtahi et al. 2018; Saeidnia et al. 2019).

Estimation of heritability can be used for determining the influence of environmental and genetic factors on the traits of interest for assessing the efficiency of selection. Estimates of $h^{2}{ }_{n}$ were higher under deficit irrigation than at normal one for all of the traits. This may be due to the fact that 
1 environmental changes can induce changes in gene expression and increase genetic variation of these

2 traits. Lower amounts of heritability for forage yield as the most economically important trait, results

3 in smaller expected gain by direct selection on this trait. In these cases, indirect selection of the traits

4 having high heritability and high correlation with forage yield can be promising (Blum 2011). This

5 was generally consistent with previous reports in smooth bromegrass (Bromus inermis L.) (Araghi et

6 al. 2014) and orchardgrass (Jafari and Naseri 2007). be obtained from the analysis of HS progenies (Araujo et al. 2002). In the present study, HS families

In grasses such as orchardgrass, due to self-incompatibility which results to cross-pollination, developing synthetic varieties is the most common breeding method (Nguyen and Sleper 1983). In order to select parental genotypes for a synthetic variety, information about GCA is desirable and can showed a wide range of GCA for DFY. Araujo (2001) stated that large differences in GCA enable effective selection of superior parents based on a polycross progeny test. As parental genotypes F3 and F7 had higher GCA values for DFY; the parental genotypes of these families could be considered as superior parents in breeding programs.

The GE interaction has been an important and challenging issue among plant breeders, geneticists, and agronomists engaged in performance testing. The presence of GEI complicates the selection process as GEI reduces the usefulness of genotypes through minimizing the association between genotypic and phenotypic values (Crossa et al. 1990). Therefore, breeding researchers are always looking for high yield potential genotypes with low GE interactions.

According to "which-won-where" pattern of GGE biplot, the test environments could be separated into four groups. Environments E1, E4, and E10 formed one group; which had least discriminating power and was also least representative of other environments and therefore provide little or no information about the families' variability (Jalata 2011; Yan and tinker 2006). The second 
1 group included environments E5 and E7 with more discriminating power and relatively low

2 representative of other environments. Environments E6, E8, and E9 marked the third group. These

3 environments had low discriminating power and hence provide little information about studied

4 families. However, these environments showed most representative of other environments. The two

5 remaining environments, i.e. E2 and E3, fell into the forth group with more discriminating power and

6 relatively high representative of other environments. In total, environment E3 with relatively high

7 discriminating power and representative of other environments may be used to effectively select

8 superior HS families which can perform consistently best across all of the environments.

9 Results of present study indicated that GGE biplot could not separate the normal and water 10 deficit environments. The reasons for this observation could be ascribed to the amount of

environmental variation. In this study environment contributed to $58.6 \%$ of the total variation in the data. Meanwhile Gauch and Zobel (1997) stated that in normal multi-location yield experiments, location accounted for about $80 \%$ of the total variation. In barley (Hordeum vulgare) yield trials, Dehghani et al. (2006) reported that more than $80 \%$ of variation was explained by environment.

In terms of mean performance, HS families were divided into two groups. In the first group, which had above-average performance, two families of F6 and F14 were highly stable, whereas three HS families of F11, F13, and F18 showed more variability (lower stability). Other families of this group had moderate to low stability. In the second group with below-average performance, two HS families of F20 and F24 had high stability and the other families showed moderate stability. From ten foreign HS families used in this study, seven of them were placed in the first group and therefore, most of the foreign families performed better than average. Two families of F6 and F14 with high yield and highest stability can be considered as most desirable ones for different environments. 
1 However, families of F11, F13, and F18 which had high yield and low stability were desirable for 2 specific environments.

An ideal genotype should have the highest mean performance of all genotypes and be absolutely stable to show wide adaptability in the wide range of environments (Sharma et al. 2010; Akcura et al. 2011). In this respect, family F14 was identified as an ideal family, and families F5, F6, and F4 were considered as most desirable families respectively, because they were located at the closest position

7 to the ideal family. Among them two HS families of F14 and F6 which had above-average 8 performances and also were located almost on the AEC abscissa and had near-zero projections onto 9 AEC ordinate, could be considered as the most stable and desirable families. These families have 10 broad adaptation to various environments. In contrast, two high-yielding families of F4 and F5 had lower stability and therefore tended to be specifically adapted to certain environments.

In conclusion, high genotypic variation among HS families indicated the possibility to find and select desirable parental genotypes for synthetic cultivar development with high stability and forage productivity using GGE biplot analysis. Water deficit had negative effects on forage yield and its components, and increased the genotypic variation of evaluated traits. Its effects on DFY were increased from the first to fifth year of study; and its consequence manifested as decline in persistence of HS families. However, some HS families with more drought tolerance and persistence were identified in these populations. Since relatively low narrow-sense heritability was obtained for DFY; both genetic and non-genetic effects play a role in the control of this trait. Therefore, selection based on an index, which is a weighted linear combination of several traits, would be more effective to achieve genetic progress in recurrent selection programs. Results of this study verified the efficiency of the GGE biplot method for selecting stable, high yielding, and responsive families. From analysis of HS families through GGE biplot method some families (F4, F5, F6, and F14) were 
1 identified as stable ones. Among them F4 was more drought tolerant than other families. The parental

2 genotypes of these families can be suggested as superior parents for developing of synthetic varieties.

3 Moreover, crosses between contrasting genotypes would be a suitable option when planning for the

4 development of mapping population for genome studies of stability and drought tolerance in this 5 species.

$7 \quad$ Funding

8 This work was supported by the Iran National Science Foundation, Science deputy of presidency 9 [Grant number: 98025737].

10

\section{Conflicts of interests}

12 The authors declare that they have no conflict of interest.

\section{Ethics approval}

5 Not applicable.

\section{Consent to participate}

Not applicable.

21 Not applicable.

22

Availability of data and materials

24

\section{Code availability}

28 Not applicable. 


\section{Authors' contributions}

2 FS, MMM and AM conceived and designed the experiments; FS performed the experiments,

3 analyzed the data and wrote the manuscript with the supervision of MMM and AM; MRD analyzed

4 the data; $\mathrm{BH}$ performed the experiments; all authors discussed the results and reviewed the 5 manuscript.

Aastveit AH, Aastveit K (1990) Theory and application of open-pollination and polycross in forage grass breeding. Theor Appl Genet 79:618-624. https://doi.org/10.1007/BF00226874

Abtahi M, Majidi MM, Mirlohi A (2018) Marker-based parental selection to improve performance of

Abtahi M, Majidi MM, Saeidnia F, Bahrami S, Mirlohi A (2019) Genetic and physiological aspects of drought tolerance in smooth bromegrass. Crop Sci 59:1-7. doi: 10.2135/cropsci2019.05.0288

Akçura M, Taner S, Kaya Y (2011) Evaluation of bread wheat genotypes under irrigated multienvironment conditions using GGE biplot analyses. Agriculture 98:35-40.

Allen RG, Pereira LS, Raes D, Smith M (1998) Crop evapotranspiration: Guidelines for computing crop requirements. FAO Irrigation and Drainage Paper, 56, 41-51.

Amini F, Majidi MM, Mirlohi A (2013) Genetic and genotype $\times$ environment interaction analysis for agronomical and some morphological traits in half-Sib families of tall fescue. Crop Science 53:411-421. doi:10.2135/cropsci2012.05.0277 
1 Amira JO, Ojo DK, Ariyo OJ, Oduwaye OA, Ayo-Vaughan MA (2013) Relative discriminating powers Of GGE and AMMI models in the selection of tropical soybean genotypes. Afr Crop Sci J 2:67-73. doi:10.3923/ijpbg.2013.139.145

Annicchiarico P, Pecetti L, Bouzerzour H, Kallida R, Khedim A, Porqueddu C, Simões NM, Volaire F, Lelièvre F (2011) Adaptation of contrasting cocksfoot plant types to agricultural environments across the Mediterranean basin. Environ Exp Bot 74:82-89. doi:10.1016/j.envexpbot.2011.05.002

Araghi B, Barati M, Majidi MM, Mirlohi A (2014) Application of half-sib mating for genetic analysis of forage yield and related traits in Bromus inermis. Euphytica 196:25-34. doi:10.1007/s10681$\underline{013-1011-2}$

Araujo MRA (2001) Variation and heritability in meadow bromegrass (Bromus riparius Rehm.). PhD thesis. University of Saskatchewan, Saskatoon

Araujo MRA, Coulman BE, Rakow G (2002) Genetic variation, heritability and progeny testing in meadow bromegrass. Plant Breed 121:417-424. doi:10.1046/j.1439-0523.2002.739124.x

Blanche SB, Myers GO, Kang MS (2007) GGE biplots and traditional stability measures for interpreting genotype by environment interactions. $\mathbf{J}$ Crop Improv 20:123-135. https://doi.org/10.1300/J411v20n01 07

Blum A (2011) Plant breeding for water limited environments. Springer, New York

Brar KS, Singh P, Mittal VP, Singh P, Jakhar ML, Yadav Y, Sharma MM, Shekhawat US, Kumar C (2010) GGE biplot analysis for visualization of mean performance and stability for seed yield in taramira at diverse locations in India. Journal of Oilseed Brassica 1:66-74. 
1 Cai H, Tian S, Liu C, Dong H (2011) Identification of a MYB3R gene involved in drought, salt and

2 cold stress in wheat (Triticum aestivum L.). Gene 485:146-152. https://doi.org/10.1016/j.gene.2011.06.026

Chaves MM, Flexas J, Pinheiro C (2009) Photosynthesis under drought and salt stress: regulation mechanisms from whole plant to cell. Ann Bot 103:551-560. doi:10.1093/aob/mcn125

Ciais P, Reichstein M, Viovy N, Granier A, Ogée J, Allard V, et al. (2005) Europe-wide reduction in primary productivity caused by the heat and drought in 2003. Nature 437:529-533. https://doi.org/10.1038/nature03972

Clarke Topp C, Parkin GW, Ferre TPA (2008) Soil water content. In: Carter MR, Gregorich EG (eds) Soil sampling and methods of analysis. Canadian Society of Soil Science, Pinawa, pp. 939-961

Crisp PA, Ganguly D, Eichten SR, Borevitz JO, Pogson BJ (2016) Reconsidering plant memory: Intersections between stress recovery, RNA turnover, and epigenetics. Sci Adv 2:e1501340. doi: 10.1126/sciadv. 1501340.

Crossa J, Gauch HG, Zobel RW (1990) Additive main effects and multiplicative interaction analysis of two international maize cultivar trials. Crop Sci 30:493-500. doi:10.2135/cropsci1990.0011183X003000030003x

Cullen BR, Johnson IR, Eckard RJ, Lodge GM, Walker RG, Rawnsley RP, McCaskill MR (2009) Climate change effects on pasture systems in South-Eastern Australia. Crop Pasture Sci 60:933942. doi:10.1071/CP09019

Dehghani H, Ebadi A, Yousefi A (2006) Biplot analysis of genotype by environment interaction for Barley yield in Iran. Agron J 98:388-393. doi:10.2134/agronj2004.0310

Eberhart SA, Russell WA (1966) Stability parameters for comparing varieties. Crop Sci 6:36-40. https://doi.org/10.2135/cropsci1966.0011183X000600010011x 
1 Fan XM, Kang MS, Chen H, Zhang Y, Tan J, Xu C (2007) Yield stability of maize hybrids evaluated

2 in multi environment trials in Yunnan, China. Agron J 99:220-228. doi:10.2134/agronj2006.0144

3 Fernandez GCJ (1992) Effective selection criteria for assessing plant stress tolerance. In: Kuo CC

$4 \quad$ (ed) Proceeding of an international symposium on adaptation of food crops to temperature and water stress. AVRDC, Shanhua, Taiwan, pp 257-270.

Finlay KW, Wilkinson GN (1963) The analysis of adaptation in a plant breeding program. Aust J

Agric Res 14:742-754. doi:10.1071/AR9630742

Gauch HG (2006) Statistical analysis of yield trials by AMMI and GGE. Crop Sci 46:1488-1500. doi: $10.2135 /$ cropsci2007.09.0513

Gauch H, Zobel RW (1997) Identifying mega-environments and targeting genotypes. Crop Sci 37:311-326. doi:10.2135/cropsci1997.0011183X003700020002x

IPCC (2014) Intergovernmental panel on climate change $5^{\text {th }}$ assessment report (AR5)-climate change 2014: impacts, adaptation, and vulnerability. IPCC

Jafari A, Naseri H (2007) Genetic variation and correlation among yield and quality traits in

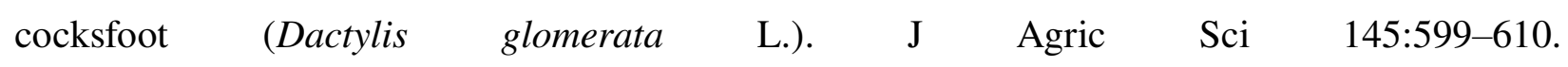
doi:https://doi.org/10.1017/S0021859607007332

Jalata Z (2011) GGE-biplot analysis of multi-environment yield trials of barley (Hordeum vulgare L.) genotypes in southeastern Ethiopia highlands. International Journal of Plant Breeding and Genetics 5:59-75. doi:10.3923/ijpbg.2011.59.75

Jandong EA, Uguru MI, Oyiga BC (2011) Determination of yield stability of seven soybean (Glycine max) genotypes across diverse soil pH levels using GGE biplot analysis. J Appl Biosci 43:29242941. 
1 Kaya Y, Akcura M, Taner S (2006) GGE-biplot analysis of multi-environment yield trials in bread $2 \quad$ wheat. Turk J Agric For 30:325-337.

Majidi MM, Hosseini B, Barati M, Mirlohi A, Araghi B (2016) Simultaneous selection for seed and forage production in cocks-foot: application of drought tolerance and susceptibility indices. Grass Forage Sci 72:441-453. https://doi.org/10.1111/gfs.12256

Nguyen HT, Sleper DA (1983) Theory and application of half-sib matings in forage breeding. Theor Appl Genet 64:187-196. https://doi.org/10.1007/BF00303763

Oral E, Kendal E, Dogan Y (2018) Selection the best barley genotypes to multi and special environments by AMMI and GGE biplot models. Fresenius Environ Bull 27:5179-5187. https://hdl.handle.net/20.500.12514/1282

Saeidnia F, Majidi MM, Abdollahi Bakhtiari M, Mirlohi A (2020) Influence of water deficit and defoliation managements on post-drought recovery and persistence of smooth bromegrass. Agron J 112:4578-4586. https://doi.org/10.1002/agj2.20395

Saeidnia F, Majidi MM, Mirlohi A, Bahrami S (2019) Inheritance and combining ability of persistence and drought recovery in smooth bromegrass (Bromus inermis L.). Euphytica 215:177. https://doi.org/10.1007/s10681-019-2500-8

Saeidnia F, Majidi MM, Mirlohi A, Soltan S (2017) Physiological and tolerance indices useful for drought tolerance selection in bromegrass. Crop Sci 57:282-289. doi:10.2135/ cropsci2016.07.0636

Samonte SOPB, Wilson LT, McClung AM, Medley JC (2005) Targeting cultivars onto rice growing environments using AMMI and SREG GGE biplot analysis. Crop Sci 45:2414-2424. doi: $10.2135 /$ cropsci2004.0627 
1 Segherloo AE, Sabaghpour SH, Dehghani H, Kamrani M (2010) Screening of superior chickpea genotypes for various environments of Iran using genotype plus genotypexenvironment (GGE) biplot analysis. J Plant Breed Crop Sci 2:286-292.

Sharma RC, Morgounov AI, Braun HJ, Akin B, Keser M, Bedoshvili D, ... Ginkel M (2010) Identifying high yielding stable winter wheat genotypes for irrigated environments in Central and West Asia. Euphytica 171:53-64. http://dx.doi.org/10.1007/s10681-009-9992-6

Steel RGD, Torrie JG (1980) Principles and procedures of statistics. McGraw-Hill Book, New York

Teodoro PE, Almeida Filho JE, Daher RF, Menezes CB, Cardoso MJ, Godinho VPC, Torres FE, Tardin FD (2015) Identification of sorghum hybrid s with high phenotypic stability using GGE biplot methodology. Genet Mol Res 15:1-8. http://dx.doi.org/10.4238/gmr.15027914

Wricke G, Weber WE (1986) Quantitative genetics and selection in plant breeding. Walter de Gruyter Press, New York

Yan W (2001) GGE biplot a windows application for graphical analysis of multi-environment trial data and other types of two-way data. Agron J 93:1111-1118. doi:10.2134/agronj2001.9351111x

Yan W (2002) Singular-value partitioning in biplot analysis of multi-environment trial data. Agron J 94:990-996. doi:10.2134/agronj2002.0990

Yan W, Cornelius PL, Crossa J, Hunt LA (2001) Two types of GGE biplots for analyzing multienvironment trial data. Crop Sci 41:656-663. doi:10.2135/cropsci2001.413656x

Yan W, Hunt LA, Sheng WQ, Szlavnics Z (2000) Cultivar evaluation and mega-environment investigation based on the GGE biplot. Crop Sci 40:597-605. https://doi.org/10.2135/cropsci2000.403597x

Yan W, Kang MS (2003) GGE biplot analysis: a graphical tool for breeders, geneticists and agronomists. 1st Edn., CRC Press LLC., Boca Roton, Florida. p. 271. 
1 Yan W, Kang MS, Ma B, Woods S, Cornelius PL (2007) GGE biplot vs. AMMI analysis of 2 genotype-by-environment data. Crop $\quad$ Sci $\quad$ 47:641-653.

$3 \quad$ https://doi.org/10.2135/cropsci2006.06.0374

4 Yan W, Tinker NA (2006) Biplot analysis of multi-environment trial data: Principles and 5 applications. Can J Plant Sci 86:623-645. https://doi.org/10.4141/P05-169

6 Zhang PP, Song H, Xi-Wang K, Xi-Jun J, Li-hua Y, Yang L, Yang QU, Wang SU (2016) GGE biplot 7 analysis of yield stability and test location representativeness in proso millet (Panicum 8 miliaceum L.) genotypes. J Integr Agric 15:1218-1227. doi:10.1016/S2095-3119(15)61157-1

9 Zobel RW, Wright MJ, Gauch HG (1988) Statistical analysis of a yield trial. Agron J 80:388-393. doi:10.2134/agronj1988.00021962008000030002x 
Table 1- Codes, origin, general combining ability (GCA), stress tolerance index (STI), and persistence (PER) of 25 half-sib families of orchardgrass evaluated in five years at two irrigation regimes

\begin{tabular}{|c|c|c|c|c|}
\hline $\begin{array}{l}\text { Codes of } \\
\text { families }\end{array}$ & Origin & $\begin{array}{c}\text { GCA of parents } \\
\text { (g per plant) }\end{array}$ & STI & $\begin{array}{c}\text { PER } \\
\text { (g per plant) }\end{array}$ \\
\hline $\mathrm{F} 1$ & Hungary & -2.86 & 0.605 & -45.56 \\
\hline $\mathrm{F} 2$ & Iran, Semnan & 4.18 & 0.697 & -56.92 \\
\hline F3 & Iran, Najafabad & -15.20 & 0.467 & -32.61 \\
\hline $\mathrm{F} 4$ & Hungary & 8.68 & 1.486 & -47.89 \\
\hline F5 & Hungary & 8.53 & 0.921 & -46.39 \\
\hline F6 & Hungary & 4.23 & 0.812 & -70.65 \\
\hline F7 & Iran, Isfahan & 9.87 & 1.288 & -52.99 \\
\hline F8 & Iran, Kuhrang & 7.12 & 0.685 & -39.44 \\
\hline F9 & Iran, Isfahan & -3.66 & 0.551 & -32.38 \\
\hline F10 & Netherland & 6.13 & 0.683 & -41.53 \\
\hline F11 & Hungary & 8.15 & 0.561 & -21.10 \\
\hline F12 & Iran, Isfahan & -9.92 & 0.497 & -26.26 \\
\hline F13 & Iran, Najafabad & 8.81 & 0.950 & -44.37 \\
\hline F14 & Iran, Isfahan & 5.37 & 0.647 & -41.93 \\
\hline F15 & Iran, Semnan & 1.88 & 0.645 & -51.59 \\
\hline F16 & Iran, Isfahan & -1.14 & 0.505 & -30.41 \\
\hline F17 & Iran, Isfahan & -6.97 & 0.602 & -31.50 \\
\hline F18 & Hungary & 0.58 & 1.318 & -64.57 \\
\hline F19 & Iran, Isfahan & -4.58 & 0.666 & -42.58 \\
\hline F20 & Iran, Semnan & -5.85 & 0.535 & -37.91 \\
\hline $\mathrm{F} 21$ & Hungary & -7.99 & 0.575 & -27.82 \\
\hline $\mathrm{F} 22$ & Hungary & -2.77 & 0.541 & -28.89 \\
\hline F23 & Iran, Isfahan & -4.39 & 0.577 & -21.05 \\
\hline F24 & Iran, Najafabad & -2.83 & 0.648 & -40.20 \\
\hline $\mathrm{F} 25$ & Hungary & -5.38 & 0.644 & -48.31 \\
\hline
\end{tabular}

1

2

3

4

5 
Table 2- Results of analysis of variance for forage yield of 25 half-sib families of orchardgrass evaluated in 10 environments (five years and two irrigation regimes).

\begin{tabular}{|c|c|c|c|c|}
\hline Source of variation & $\mathrm{df}$ & Sum of squares & Mean squares & Total variation \\
\hline Environment (E) & 9 & 307181.94 & $34131.33 * *$ & $58.60 \%$ \\
\hline Replication /E & 10 & 8191.71 & 819.17 & \\
\hline Genotype (G) & 24 & 29834.30 & $1243.10 * *$ & $4.22 \%$ \\
\hline Iranian (I) & 15 & 20150.98 & $1439.36^{* *}$ & \\
\hline Foreign $(\mathrm{F})$ & 8 & 8290.91 & $921.21^{* *}$ & \\
\hline $\mathrm{I} \times \mathrm{F}$ & 1 & 1392.42 & $1392.42^{*}$ & \\
\hline $\mathrm{G} \times \mathrm{E}$ & 216 & 112959.93 & $522.96 * *$ & $21.55 \%$ \\
\hline Error & 229 & 73740.53 & 307.25 & \\
\hline Total & 488 & 524204.10 & & \\
\hline
\end{tabular}

1

2

3

4

5

6

7

8

9

10

11

12 
Table 3- Means of phenological and agronomic traits of 25 half-sib families of orchardgrass under normal and deficit irrigation during 2010-2014.

\begin{tabular}{|c|c|c|c|c|c|c|c|c|c|c|c|c|c|c|c|}
\hline \multirow[b]{2}{*}{ Traits } & \multicolumn{3}{|c|}{2010} & \multicolumn{3}{|c|}{2011} & \multicolumn{3}{|c|}{2012} & \multicolumn{3}{|c|}{2013} & \multicolumn{3}{|c|}{2014} \\
\hline & Normal & Deficit & $\begin{array}{c}\text { Change† } \\
(\%)\end{array}$ & Normal & Deficit & $\begin{array}{c}\text { Change } \\
(\%)\end{array}$ & Normal & Deficit & $\begin{array}{c}\text { Change } \\
(\%)\end{array}$ & Normal & Deficit & $\begin{array}{c}\text { Change } \\
(\%)\end{array}$ & Normal & Deficit & $\begin{array}{c}\text { Change } \\
(\%)\end{array}$ \\
\hline DPE (day) & 73.40 & 76.98 & $4.88^{* *}$ & 40.61 & 35.17 & $-13.39^{* *}$ & 44.25 & 32.85 & $-25.76^{* *}$ & 46.60 & 35.20 & $-24.46^{* *}$ & 73.06 & 66.68 & $-8.73^{*}$ \\
\hline DA (day) & 80.73 & 84.30 & $4.42^{*}$ & 55.14 & 49.72 & $-9.83^{*}$ & 63.85 & 52.28 & $-18.12^{*}$ & 66.20 & 54.63 & $-17.48^{*}$ & 87.66 & 78.06 & $-10.95^{* *}$ \\
\hline $\mathrm{PH}(\mathrm{cm})$ & 85.15 & 79.32 & $-6.85^{\text {n.s }}$ & 85.06 & 75.18 & $-11.62^{*}$ & 82.69 & 68.13 & $-17.61^{*}$ & 83.19 & 64.23 & $-22.79^{* *}$ & - & - & - \\
\hline NS & 5.79 & 3.78 & $-34.72^{*}$ & 41.44 & 37.21 & $-10.21^{\mathrm{n} . \mathrm{s}}$ & 122.07 & 63.01 & $-48.38^{*}$ & 129.96 & 65.99 & $-49.22^{*}$ & - & - & - \\
\hline $\mathrm{CD}(\mathrm{cm})$ & 13.78 & 11.33 & $-17.78^{* *}$ & 25.33 & 21.41 & $-15.47^{* *}$ & 23.77 & 19.29 & $-18.85^{* *}$ & 24.75 & 20.27 & $-18.10^{* *}$ & 24.28 & 21.54 & $-11.28^{* *}$ \\
\hline DFY1 (g/plant) & 82.91 & 64.58 & $-22.11^{*}$ & 106.67 & 74.68 & $-29.99^{*}$ & 98.38 & 34.92 & $-64.50^{* *}$ & 102.87 & 31.85 & $-69.04^{* *}$ & 58.33 & 41.11 & $-29.52^{*}$ \\
\hline PDFY1 (\%) & 36.26 & 46.57 & $28.43^{*}$ & 35.53 & 45.30 & $27.50^{*}$ & 42.69 & 50.11 & $17.38^{*}$ & 43.79 & 50.52 & $15.37^{*}$ & 37.30 & 47.16 & $26.43^{*}$ \\
\hline DFY2 (g/plant) & 107.04 & 88.85 & $-16.99^{*}$ & 63.86 & 35.17 & $-44.93^{*}$ & 28.03 & 10.66 & $-61.97^{* *}$ & 32.61 & 11.32 & $-65.29^{* *}$ & 30.27 & 17.58 & $-41.92^{*}$ \\
\hline PDFY2 (\%) & 33.11 & 42.05 & $27.00^{*}$ & 35.23 & 40.33 & $14.48^{*}$ & 39.84 & 45.85 & $15.08^{*}$ & 42.46 & 50.02 & $17.80^{*}$ & 30.11 & 37.52 & $24.61^{*}$ \\
\hline
\end{tabular}

DPE, days to panicle emergence; DA, days to anthesis; PH, plant height; NS, number of stems per plant; CD, crown diameter; DFY1 and 2, dry forage yield of

cuts 1 and 2; PDFY1 and 2, percentage dry forage yield of cuts 1 and 2.

$\uparrow$ The test of null hypothesis for 'Change' is computed from comparison means based on an ANOVA per year. 
Table 4- Estimates of variance components, narrow-sense heritability $\left(\mathrm{h}^{2}\right)$, and genetic coefficient of variation (GCV) of measured traits in 25 half-sib families of orchardgrass under normal and deficit irrigations during 2010-2014. These results come from the combined ANOVA per irrigation regime.

\begin{tabular}{|c|c|c|c|c|c|c|c|c|c|c|c|c|}
\hline \multirow{2}{*}{ Traits } & \multicolumn{5}{|c|}{ Normal irrigation } & \multicolumn{5}{|c|}{ Deficit irrigation } & \multicolumn{2}{|c|}{ GCV } \\
\hline & $\sigma_{\mathrm{f}}^{2}$ & $\sigma_{\text {fy }}^{2}$ & $\sigma_{\mathrm{e}}^{2}$ & $\sigma_{p}^{2}$ & $h^{2}{ }_{n}$ & $\sigma_{\mathrm{f}}^{2}$ & $\sigma_{\text {fy }}^{2}$ & $\sigma_{\mathrm{e}}^{2}$ & $\sigma_{p}^{2}$ & $\mathrm{~h}^{2}{ }_{\mathrm{n}}$ & Normal & Stress \\
\hline DPE & 3.45 & 3.20 & 16.07 & 7.62 & 45.27 & 9.44 & 2.43 & 18.55 & 12.53 & 75.35 & 3.34 & 6.22 \\
\hline DA & 6.54 & 2.73 & 15.42 & 11.41 & 57.36 & 6.37 & 1.17 & 15.30 & 11.22 & 56.77 & 3.62 & 3.96 \\
\hline $\mathrm{PH}$ & 6.88 & 0.46 & 35.00 & 20.28 & 33.93 & 7.71 & -0.70 & 32.39 & 20.13 & 38.32 & 3.12 & 3.87 \\
\hline NS & 55.59 & -2.54 & 664.70 & 202.49 & 27.45 & 96.30 & 40.26 & 267.35 & 185.32 & 51.97 & 9.97 & 23.09 \\
\hline $\mathrm{CD}$ & 0.07 & 0.10 & 1.04 & 0.22 & 32.33 & 0.14 & 0.12 & 0.66 & 0.22 & 62.88 & 1.18 & 1.99 \\
\hline DFY1 & 76.35 & 458.88 & 1201.62 & 414.70 & 18.41 & 14.23 & 41.34 & 165.47 & 53.10 & 26.80 & 9.73 & 7.63 \\
\hline PDFY1 & 3.62 & 4.72 & 56.34 & 14.74 & 24.53 & 5.54 & 7.07 & 25.50 & 11.45 & 48.38 & 4.86 & 4.91 \\
\hline DFY2 & 7.40 & 44.46 & 119.11 & 51.66 & 14.33 & 9.43 & 24.65 & 96.66 & 36.74 & 25.66 & 5.20 & 9.39 \\
\hline PDFY2 & 0.66 & 6.35 & 8.21 & 3.66 & 18.09 & 5.52 & -1.30 & 67.01 & 18.74 & 29.46 & 2.25 & 5.44 \\
\hline
\end{tabular}

DPE, days to panicle emergence; DA, days to anthesis; PH, plant height; NS, number of stems per plant; CD, crown diameter; DFY1 and 2, dry forage yield of cuts 1 and 2; PDFY1 and 2, percentage dry forage yield of cuts 1 and 2.

$\sigma^{2}$, family variance; $\sigma_{\text {fy }}^{2}$, family $\times$ year variance; $\sigma^{2}$, error variance; $\sigma^{2}$, phenotypic variance; $h^{2}$, narrow-sense heritability; GCV, genetic coefficient of variation. Negative values of variance components assumed to be zero for estimation of heritability. 


\section{$1 \quad$ Figure captions}

2 Fig. 1- Biplots of stress tolerance index (STI) vs (a) general combining ability (GCA) and (b)

3 persistence (PER) for 25 families of orchardgrass. The red codes refer to foreign families and the

$4 \quad$ black codes to Iranian families

5 Fig. 2- 'Polygon' view of the GGE biplot to show which family performed better in which

6 environment for forage yield of orchardgrass

7 Fig. 3- GGE biplot showing the ranking of HS families of orchardgrass based on yield performance 8 and stability

9 Fig. 4- GGE biplot showing the performance of each HS families of orchardgrass in each

10 environment

Fig. 5- Comparison of HS families of orchardgrass against the position of an 'ideal' genotype for forage yield and stability of performance across the environments

Fig. 6- GGE biplot showing the ranking of HS families of orchardgrass based on yield performance and stability 
Figures

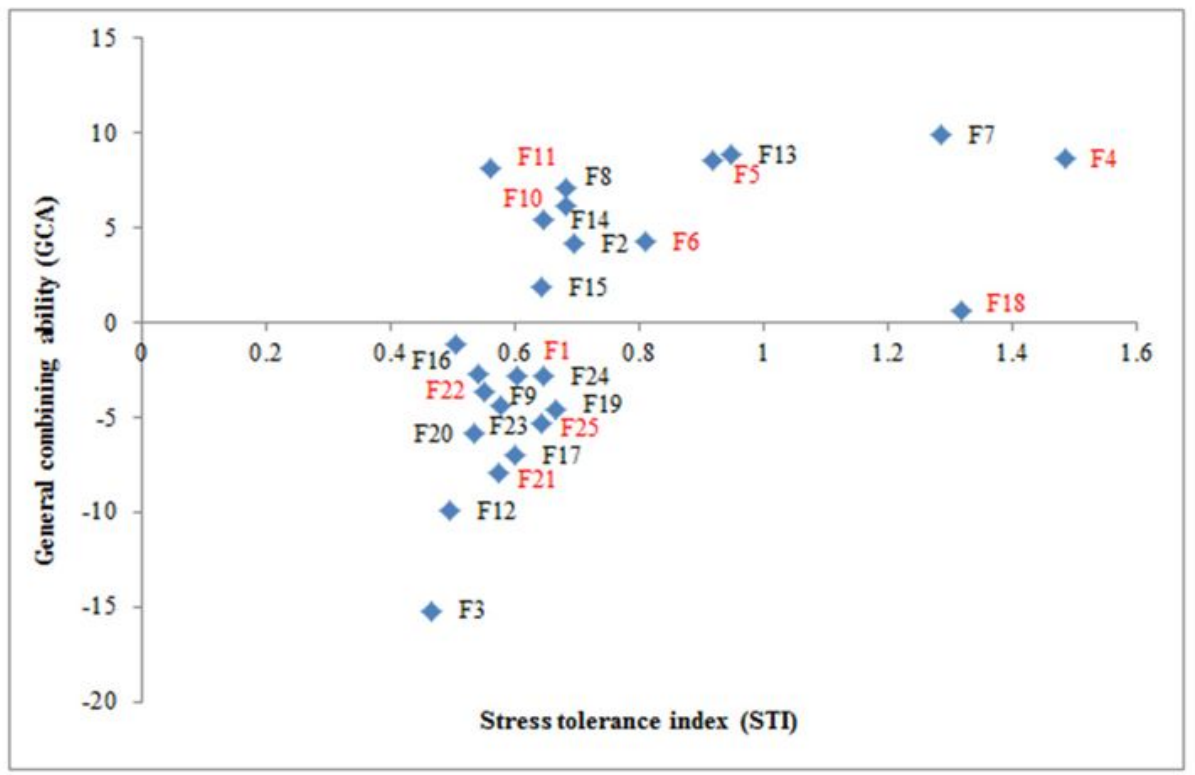

(a)

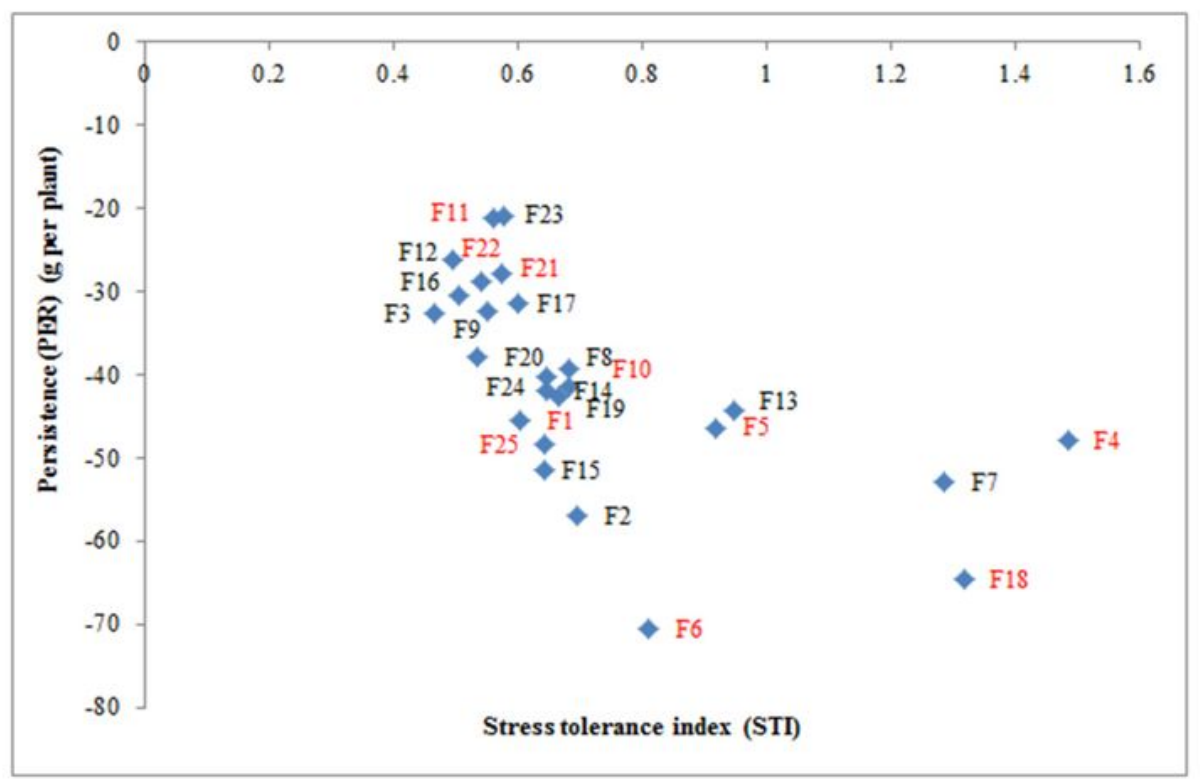

(b)

\section{Figure 1}

Biplots of stress tolerance index (STI) vs (a) general combining ability (GCA) and (b) persistence (PER) for 25 families of orchardgrass. The red codes refer to foreign families and the black codes to Iranian families 


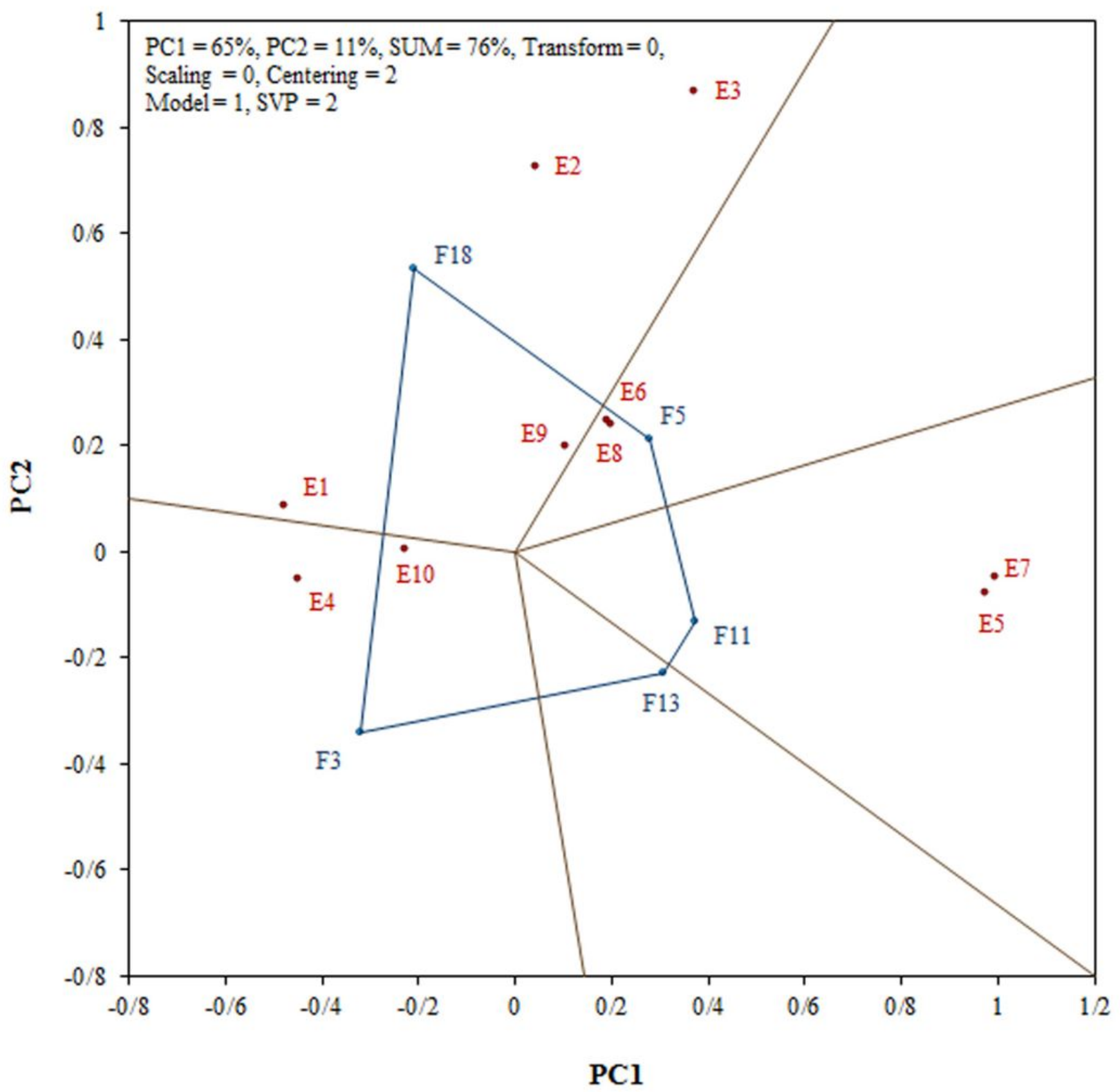

Figure 2

'Polygon' view of the GGE biplot to show which family performed better in which environment for forage yield of orchardgrass 


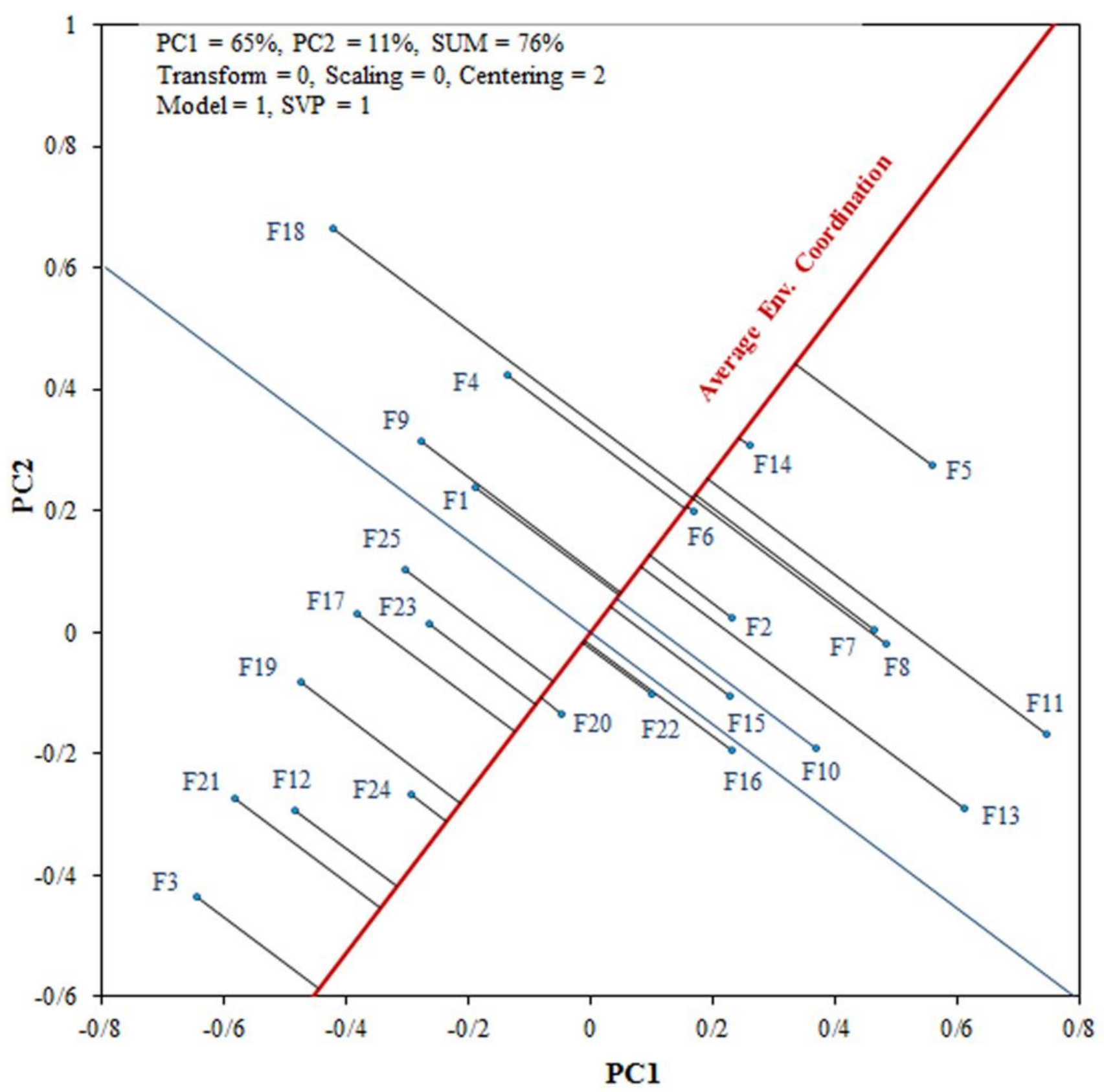

Figure 3

GGE biplot showing the ranking of HS families of orchardgrass based on yield performance and stability 


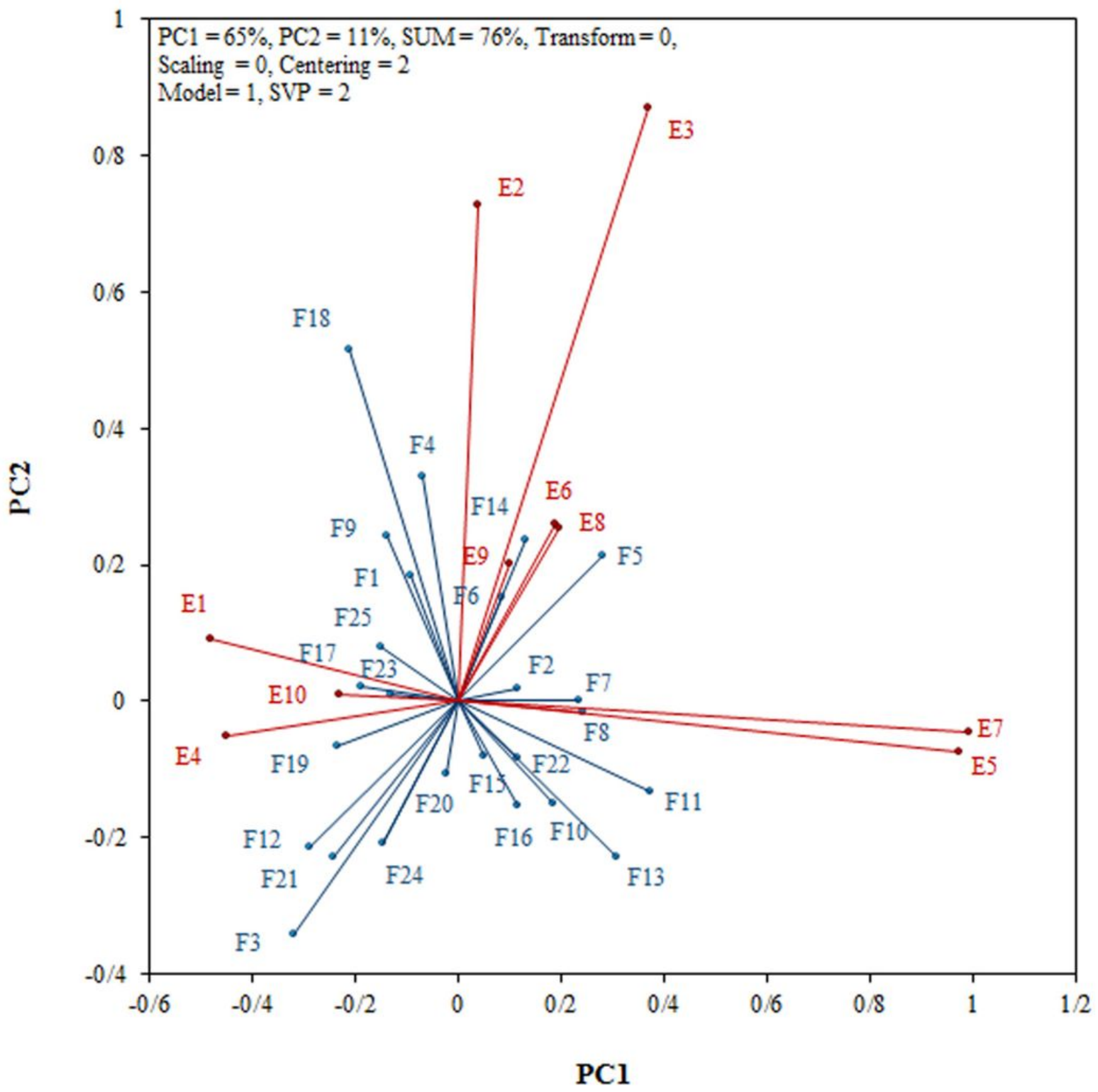

Figure 4

GGE biplot showing the performance of each HS families of orchardgrass in each environment 


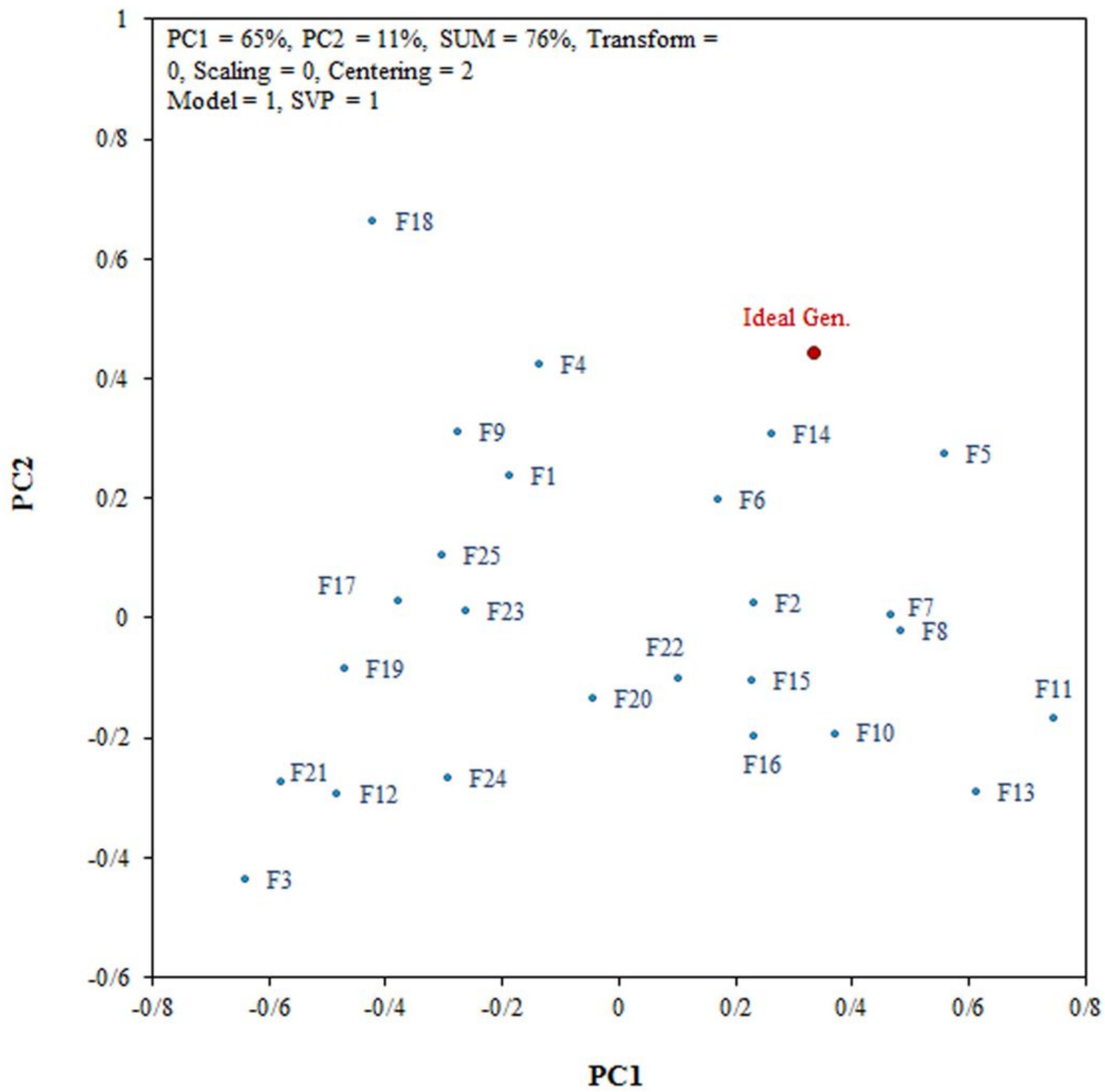

Figure 5

Comparison of HS families of orchardgrass against the position of an 'ideal' genotype for forage yield and stability of performance across the environments 


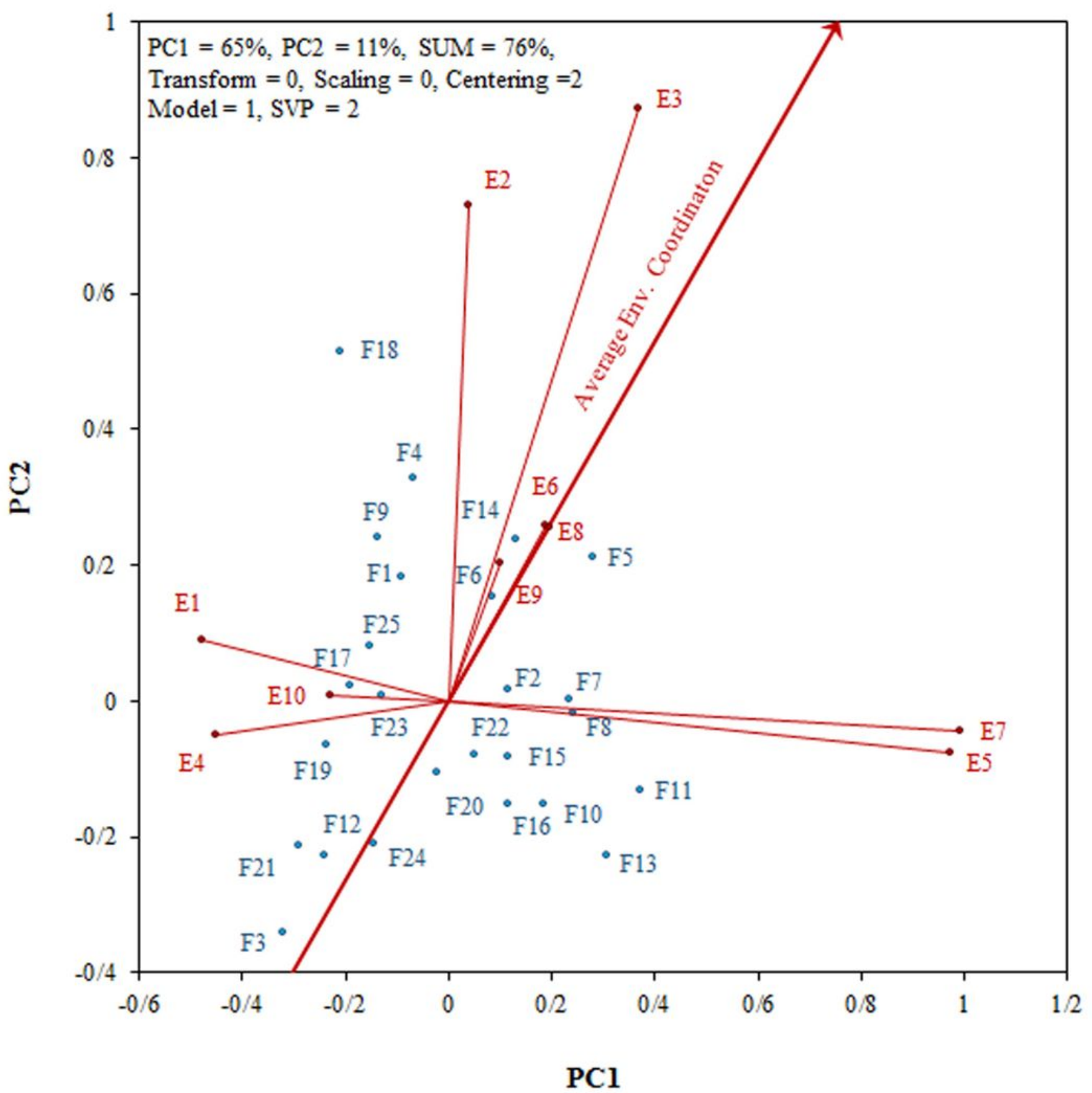

Figure 6

GGE biplot showing the ranking of HS families of orchardgrass based on yield performance and stability

\section{Supplementary Files}

This is a list of supplementary files associated with this preprint. Click to download. 
- Supplementarylnformation.doc 